\title{
SKRINING PENYAKIT DIABETES MELLITUS DI DESA PEMECUTAN KAJA DENPASAR UTARA
}

\author{
Febianingsih, Ni Putu Eka ${ }^{\text {* }}$; Yudhawati, NLP Suardini ${ }^{1}$; Widyanata, Kmg Agus \\ Jerry ${ }^{1}$; Wardita, I Wayan ${ }^{1}$; Dira, I Ketut ${ }^{1}$; Dewi, NLM Asri ${ }^{1}$; \\ Putra, I Gede Yudiana ${ }^{1}$
}

\author{
${ }^{1}$ Akademi Keperawatan Kesdam IX/Udayana \\ *Korespondensi: putuekafebi@gmail.com
}

\begin{abstract}
Background: New cases of Diabetes Mellitus (DM) in Bali Province from 2011 to 2013 were increased. Based on the report of Integrated Disease Surveillance or Surveilan Terpadu Penyakit (STP) from Puskesmas it is known that DM was ranked 3 out of the 10 highest diseases in health centers throughout the City of Denpasar. The purpose of this screening is to find out the prevalence of DM in Pemecutan Kaja Village, North Denpasar in 2015. Methods: Screening was carried out on 189 subjects aged $\geq 15$ in Pemecutan Kaja Village, North Denpasar on January 6 and 7 , 2015. Screening was carried out by checking blood sugar levels while using Nesco Multicheck. The collected data is processed and presented descriptively about the characteristics of the sample and the proportion of DM based on the results of the examination. Results: The results showed that $6.4 \%$ of respondents suffering DM. Most of the subjects were women (58.3\%). In this screening, there are $50 \%$ in the age group $\geq 51$ years, and most are only elementary school graduates $(30 \%)$. Based on the type of work, most of the subjects are entrepreneurs/traders $(50 \%)$. Based on the interview, there was none history of DM in the family. Conclusion: The proportion of DM in Pemecutan Kaja Village is 6.4\% through examination of blood sugar levels while using Nesco Multi Check. The positive results of DM in this screening should be carried out further examination to confirm the diagnosis so that appropriate treatment can be carried out.
\end{abstract}

Keywords: Diabetes Mellitus, Screening, Pemecutan Kaja, North Denpasar,

\begin{abstract}
ABSTRAK
Latar Belakang: Kasus baru DM di Provinsi Bali dari tahun 2011 sampai dengan 2013 semakin meningkat. Berdasarkan laporan Surveilan Terpadu Penyakit (STP) dari Puskesmas diketahui bahwa DM menduduki peringkat 3 dari 10 penyakit tertinggi di puskesmas se-Kota Denpasar. Tujuan skrining ini adalah untuk mengetahui prevalensi DM di Desa Pemecutan Kaja Denpasar Utara tahun 2015. Metode: Skrining dilaksanakan terhadap 189 subjek berusia $\geq 15$ tahun di Desa Pemecutan Kaja Denpasar Utara pada tanggal 6 dan 7 Januari 2015. Skrining dilakukan melalui pemeriksaan kadar gula darah sewaktu menggunakan Nesco Multicheck. Data yang terkumpul diolah dan disajikan secara deskriptif mengenai karakteristik sampel dan proporsi DM berdasarkan hasil pemeriksaan. Hasil: Sebanyak 6,4\% responden mengalami DM. Sebagian besar subyek mengalami DM
\end{abstract}

$\begin{array}{ll}\text { Akademi Keperawatan Kesdam IX/Udayana } & 7\end{array}$ 
adalah perempuan (58,3\%). Pada skrining ini sebanyak 50\% pada kelompok umur $\geq 51$ tahun, dan sebagian besar hanya lulusan SD (30\%). Berdasarkan jenis pekerjaan, sebagian besar subjek merupakan wiraswasta/pedagang (50\%). Berdasarkan wawancara tidak ditemukan adanya riwayat DM pada keluarga. Simpulan: Proporsi DM di Desa Pemecutan Kaja adalah 6,4\% melalui pemeriksaan kadar gula darah sewaktu menggunakan Nesco Multi check. Hasil positif DM pada skrining ini hendaknya dilakukan pemeriksaan lebih lanjut untuk penegakan diagnosa agar dapat dilakukan pengobatan yang tepat.

Kata kunci : Diabetes Mellitus, Skrining, Pemecutan Kaja

\section{PENDAHULUAN}

Transisi epidemiologi menyebabkan beban ganda bagi masyarakat Indonesia. Selain penyakit infeksi, saat ini Indonesia juga dihadapkan dengan masalah penyakit non infeksi/tidak menular. Salah satu penyakit tidak menular yang jumlah kasusnya semakin meningkat adalah Diabetes Melitus (DM). Penyakit DM merupakan salah satu penyakit degeneratif yang ditandai dengan hiperglikemia (peningkatan kadar gula darah) akibat adanya gangguan endokrin.

Berdasarkan berbagai penelitian epidemiologi di Indonesia didapatkan angka kejangkitan penyakit DM sebesar 1,55 - 2,3\% terjadi pada penduduk usia lebih dari 15 tahun. Data Riskesdas tahun 2013 menunjukkan bahwa penyakit tidak menular di Indonesia cenderung meningkat dari tahun 2007 hingga 2013. Prevalensi Diabetes Melitus (DM) juga mengalami peningkatan dari 1,1\% di tahun 2007 menjadi 2,1\% di tahun 2013 (Kemenkes RI, 2013)

Kasus baru DM di Provinsi Bali dari tahun 2011 sampai dengan 2013 dilaporkan semakin meningkat. Berdasarkan laporan Surveilans Terpadu Penyakit (STP) dari Puskesmas diketahui bahwa DM menduduki peringkat 3 dari 10 penyakit tertinggi di puskesmas se Kota Denpasar. Jumlah kasus pada tahun 2011 adalah 727, pada tahun 2012 menurun menjadi 661 kasus, kemudian pada tahun 2013 meningkat sangat tajam hingga mencapai 14.667 kasus (Dinas Kesehatan Prov Bali, 2013). Peningkatan ini kemungkinan terjadi karena metode skrining sebagai deteksi dini kasus yang diterapkan dalam kegiatan Posbindu semakin baik.

Posbindu merupakan bentuk pemberdayaan masyarakat dalam upaya penanggulangan penyakit tidak menular. Program Penyakit Tidak Menular (PTM) masuk sebagai salah satu program dalam Rencana Strategi Kementerian Kesehatan Tahun 2010-2014. Indikator dalam program ini adalah tercapainya cakupan 
surveilans, deteksi dini, dan tatalaksana kasus 100\% (Kemenkes RI, 2013). Kegiatan Posbindu mencakup pemeriksaan termasuk deteksi dini penyakit tidak menular yaitu pemeriksaan tekanan darah untuk Hipertensi, pemeriksaan Inspeksi Visual Asam Asetat (IVA) untuk suspek Kanker Serviks, pemeriksaan dislipidemia sebagai faktor risiko penyakit jantung iskemik dan stroke, serta alat untuk pemeriksaan kadar gula darah untuk penyakit DM

Dinas Kesehatan Provinsi Bali telah menargetkan sebanyak 65 Posbindu Mandiri yang akan terbentuk di Provinsi Bali. Posbindu di Kota Denpasar telah terbentuk di seluruh wilayah kerja Puskesmas. Namun yang baru dinyatakan aktif dan mandiri adalah posbindu yang terbentuk di wilayah kerja Puskesmas II Denpasar Barat. Bulan Oktober 2012 dilaksanakan pembentukan dan pelatihan kader Posbindu. Kegiatan posbindu mulai berjalan pada bulan Januari 2013 dengan terbentuknya 5 pos. Pertengahan tahun 2014 kader Posbindu di 5 pos tersebut dapat secara mandiri melaksanakan kegiatan posbindu.

Salah satu wilayah kerja Puskesmas yang membutuhkan inisiasi kegiatan posbindu adalah wilayah kerja Puskesmas Denpasar Utara II. Desa yang bersedia menjadi desa inisiasi Posbindu adalah Desa Pemecutan Kaja, Denpasar Utara. Sebagian besar warga di Desa Pemecutan Kaja memiliki mata pencaharian sebgai wirasawasata, yang cenderung memiliki aktivitas fisik yang rendah. Aktivitas fisik yang rendah merupakan salah satu faktor risiko penyakit tidak menular, yang salah satunya adalah DM. Dengan demikian kegiatan inisiasi Posbindu DM dilaksanakan di wilayah kerja Puskesmas II Denpasar Utara. Selain untuk menginisiasi kader dan masyarakat untuk lebih aktif dalam pelaksanaan kegiatan posbindu, khususnya deteksi dini penyakit DM, tujuan skrining ini juga untuk mengetahui gambaran prevalensi DM di daerah tersebut.

\section{METODE}

Kegiatan pengabdian masyarakat ini menggunakan pendekatan Community Service, dengan melaksanakan kegiatan skrining penyakit Diabetes Mellitus melalui pemeriksaan gula darah sewaktu terhadap masyarakat usia $\geq 15$ tahun di Banjar Tulang Ampian dan Banjar Kerta Sari Desa Pemecutan Kaja Denpasar Utara. Kegiatan dilaksanakan selama 2 hari yaitu tanggal 6 dan 7 Pebruari 2015. 
Kadar gula darah sewaktu diukur menggunakan Easy Touch GCU dengan sampel darah perifer. Data dianalisis secara deskriptif.

\section{HASIL DAN PEMBAHASAN}

Target sasaran skrining DM di Desa Pemecutan Kaja Denpasar, adalah sebanyak 200 orang, namun hanya 189 orang yang berhasil dilakukan pemeriksaan kadar gula darah. Sebagian besar subjek skrining adalah perempuan $(63,49 \%)$. Berdasarkan kelompok umur, subyek sebagian besar berusia $\geq 51$ tahun $(38,62 \%)$, dan berdasarkan mata pencaharian, sebanyak $38,10 \%$ bekerja sebagai wiraswasta/pedagang. Karakteristik subjek dijabarkan pada tabel 1.

Hasil pemeriksaan kadar gula darah terhadap 189 orang yang berusia $\geq 15$ tahun, dengan menggunakan baku emas berupa test strip Nesco dan anamnesis gejala klinis, diperoleh hasil sebanyak 12 orang dari 189 orang $(6,35 \%)$ subjek menderita DM. Pada tabel berikut disajikan karakteristik subjek yang menderita DM berdasarkan hasil skrining di Desa Pemecutan Kaja dijelaskan pada tabel 2.

Berdasarkan skrining yang telah dilakukan, sebanyak 12 orang $(6,35 \%)$ mengalami DM, sesuai dengan kriteria PERKENI (2011) yaitu kadar gula darah sewaktu $\geq 200 \mathrm{mg} / \mathrm{dl}$. Karakteristik penderita DM berdsarkan pemeriksaan gula darah sewaktu dijabarkan pada tabel 3. Sebagian besar subyek yang memiliki kadar gula darah sewaktu adalah perempuan (58,33\%). Pada skrining ini sebanyak 50\% pada kelompok umur $\geq 51$ tahun dan sebagian besar berpendidikan sekolah dasar $(30 \%)$.

Berdasarkan pekerjaan, sebagian besar subjek merupakan wirasawasta/pedagang (50\%). Akan tetapi berdasarkan riwayat DM pada keluarga, seluruh subyek menyatakan tidak terdapat riwayat DM pada keluarganya, baik ayah, ibu maupun kakek dan nenek. 
Tabel 1. Karakteristik Subjek Skrining Penderita DM di Desa Pemecutan Kaja Tahun 2015

\begin{tabular}{|c|c|c|}
\hline Karakteristik & Jumlah & Persentase (\%) \\
\hline \multicolumn{3}{|l|}{ Jenis Kelamin } \\
\hline Laki-laki & 69 & 36.51 \\
\hline Perempuan & 120 & 63.49 \\
\hline \multicolumn{3}{|l|}{ Kelompok Umur } \\
\hline $15-30$ tahun & 24 & 12,70 \\
\hline $31-40$ tahun & 28 & 14,81 \\
\hline $41-50$ tahun & 64 & 33,86 \\
\hline$\geq 51$ tahun & 73 & 38,62 \\
\hline \multicolumn{3}{|l|}{ Pendidikan } \\
\hline Tidak Sekolah & 46 & 24,34 \\
\hline $\mathrm{SD}$ & 54 & 28,57 \\
\hline SMP & 19 & 10,05 \\
\hline SMA & 57 & 30,16 \\
\hline PT & 13 & 6,88 \\
\hline \multicolumn{3}{|l|}{ Pekerjaan } \\
\hline Tdk Bekerja/Pensiunan & 8 & 4.23 \\
\hline Pelajar & 11 & 5.82 \\
\hline IRT & 48 & 25.40 \\
\hline PNS/TNI/POLRI & 5 & 2.65 \\
\hline Buruh & 15 & 7.94 \\
\hline Wiraswasta & 72 & 38.10 \\
\hline Peg.swasta & 30 & 15.87 \\
\hline Total & 189 & 100 \\
\hline
\end{tabular}

Tabel 2. Penderita DM berdasarkan pemeriksaan kadar gula darah sewaktu

\begin{tabular}{lcc}
\hline DM & Jumlah & Persentase (\%) \\
\hline Ya & 12 & 6,35 \\
Tidak & 177 & 93,65 \\
Total & 189 & 100 \\
\hline
\end{tabular}

Tabel 3. Karakteristik penderita DM berdasarkan pemeriksaan gula darah sewaktu

\begin{tabular}{lcc}
\hline Karakteristik & Jumlah & Persentase (\%) \\
\hline Jenis Kelamin & & \\
Laki-laki & 5 & 41,67 \\
Perempuan & 7 & 58,33 \\
Kelompok Umur & & \\
$15-30$ tahun & 0 & 0 \\
$31-40$ tahun & 2 & 16,67 \\
$41-50$ tahun & 4 & 33,33 \\
$\geq 51$ tahun & 6 & 50,00 \\
Pendidikan & & 25 \\
Tidak Sekolah & 3 & 30 \\
SD & 6 & \\
\hline
\end{tabular}


Tabel 3. Karakteristik penderita DM berdasarkan pemeriksaan gula darah sewaktu (Lanjutan)

\begin{tabular}{lcc}
\hline Karakteristik & Jumlah & Persentase (\%) \\
\hline SMP & 1 & 8,33 \\
SMA & 2 & 16,67 \\
PT & 0 & 0 \\
Pekerjaan & & \\
Tdk Bekerja/Pensiunan & 0 & 0 \\
Pelajar & 0 & 0 \\
IRT & 3 & 25 \\
PNS/TNI/POLRI & 0 & 0 \\
Buruh & 1 & 8,33 \\
Wiraswasta & 6 & 50,00 \\
Peg.swasta & 2 & 16,67 \\
Riwayat DM pada Keluarga & & \\
Ada & 0 & 0 \\
Tidak & 12 & 100 \\
Total & 12 & 100 \\
\hline
\end{tabular}

Beberapa hasil penelitian epidemiologi melaporkan adanya kecenderungan peningkatan angka insiden dan prevalensi DM tipe 2 di berbagai negara. Prediksi dari WHO sendiri menyatakan adanya peningkatan jumlah penderita diabetes yang cukup besar pada tahun-tahun mendatang (Soelistijo et al., 2015). WHO dan International Diabetes Federation (IDF) memprediksikan adanya peningkatan jumlah penyandang DM sebanyak 2 - 3 kali lipat di tahun 2030.

Hasil penelitian yang dilakukan di beberapa wilayah Indonesia pada rentang tahun 1980 - 2000 menunjukkan adanya peningkatan prevalensi yang sangat tajam. Pada penelitian di Jakarta prevalensi DM 1,7\% pada tahun 1982 naik menjadi 5,7\% pada tahun 1993 dan meningkat lagi pada tahun 2001 menjadi 12,8\%. Pada tahun 2013 prevalensi di Indonesia mengalami peningkatan dari 1,1\% pada tahun 2007 menjadi 2,1\% (Depkes RI, 2008)

Prevalensi DM di Provinsi Bali menjadi salah satu penyakit dengan kasus tertinggi pada tahun 2013. Penyakit DM merupakan kasus terbanyak nomor 3 di Bali berdasarkan Data 10 besar penyakit di puskesmas sentinel se- Bali(Dinas Kesehatan Provinsi Bali, 2014). Penyakit DM dihubungkan dengan berbagai macam faktor termasuk pola hidup. Denpasar merupakan salah satu daerah perkotaan di Bali dengan jumlah penduduk yang padat. karakteristik dan pola hidup yang beragam. Pada tahun 2013 tercatat sebanyak 3.821 kunjungan penderita DM di Puskesmas se Kota Denpasar. 
Salah satu upaya yang dilakukan untuk menemukan penderita secara dini di Kota Denpasar adalah dengan melakukan deteksi dini melalui skrining. Skrining ini dilakukan melalui pemeriksaan darah sewaktu atau Random Plasma Glucose (RPG). Pengukuran ini lebih mudah dilakukan di lapangan karena tidak mewajibkan subjek skrining untuk puasa sebelum pemeriksaan. Berdasarkan Oral Glucose Tolerance Test (OGTT) sebagai baku emas, RPG memiliki sensitivitas yang rendah tetapi memiliki spesifisitas $100 \%$ sehingga tidak adak positif palsu (Cox \& Edelman, 2009)

Berdasarkan hasil skrining yang telah dilakukan di Desa Pemecutan Kaja Denpasar, diperoleh hasil bahwa sebanyak 6,35\% dari 189 orang usia $\geq 15$ tahun memiliki kadar gula darah sewaktu $\geq 200 \mathrm{mg} / \mathrm{dl}$. Sebagian besar adalah perempuan (58.33\%). Secara teori penyakit DM sebagian besar dijumpai pada perempuan dibandingkan laki-laki hal ini dapat disebabkan karena perempuan memiliki LDL yang lebih tinggi dibandingkan dengan laki-laki. selain itu perempuan cenderung memiliki aktivitas yang lebih rendah. Akan tetapi berdasarkan hasil penelitian kasus kontrol yang pernah dilakukan di wilayah kerja Puskesmas Mataram II, ditemukan bahwa tidak terdapat hubungan yang bermakna antara jenis kelamin dengan kejadian DM (Jelantik \& Haryati, 2014)

Kelompok sasaran skrining ini adalah usia $\geq 15$ tahun karena kecenderungan saat ini adalah semakin meningkatnya jumlah penderita penyakit tidak menular yang masih berusia muda akibat adanya riwayat penyakit pada keluarga dan atau pola hidup yang cenderung tidak sehat. Akan tetapi hasil skrining yang telah dilakukan di Desa Pemecutan Kaja penderita DM mulai dari usia $\geq 31$ tahun dan $50 \%$ subjek skrining yang menderita DM berusia $\geq 51$ tahun. Dan dari seluruh subjek yang positif DM tidak ditemukan riwayat keluarga dengan penyakit DM.

Tidak ditemukan adanya riwayat penyakit DM pada keluarga penderita. Hal ini kemungkinan disebabkan oleh pola hidup yang tidak sehat seperti pola makan yang tidak terkontrol dan aktivitas fisik yang rendah. Berdasarkan penelitian di Puskesmas Kecamatan Cengkareng Jakarta Barat tahun 2012 menunjukkan adanya hubungan antara aktivitas fisik dengan kejadian DM tipe II. Orang dengan aktivitas fisik berat memiliki risiko lebih rendah untuk menderita DM tipe II dibandingkan dengan orang yang beraktivitas fisik sehari-hari dalam skala ringan. Aktivitas fisik 
menjadi faktor protektif atau dapat mencegah DM yang dilihat pada nilai $\mathrm{OR}=$ 0,239; 95\% CI: 0,071 - 0,802 (Trisnawati \& Setyorogo, 2013).

Rencana tindak lanjut dari kegiatan skrining ini adalah berupa pelaporan hasil skrining kepada pihak Puskesmas Denpasar Utara II. Hasil skrining ini dapat digunakan sebagai data dasar untuk program posbindu selanjutnya yang akan dilaksanakan oleh Puskesmas Denpasar Utara II bersama kader.

\section{SIMPULAN}

Hasil skrining pada masyarakat di Desa Pemecutan Kaja Denpasar, ditemukan bahwa sebanyak 6,35\% memiliki kadar gula darah sewaktu $\geq 200 \mathrm{mg} / \mathrm{dl}$. Sebagian besar adalah perempuan (58.33\%). Tidak ditemukan adanya riwayat penyakit DM pada keluarga penderita.

\section{UCAPAN TERIMAKASIH}

Kami mengucapkan terima kasih kepada Kepala Puskesmas Denpasar Utara II, Kepala Desa Pemecutan Kaja dan seluruh masyarakat Pemecutan Kaja. Terima kasih kepada Akper Kesdam IX/Udayana yang mendanai kegiatan ini secara penuh.

\section{DAFTAR PUSTAKA}

Cox, M. E., \& Edelman, D. (2009). Tests for screening and diagnosis of type 2 diabetes. Clinical Diabetes, 27(4), 132-138. https://doi.org/10.2337/diaclin.27.4.132

Depkes RI. (2008). Riset Kesehatan Dasar (RISKESDAS) 2007. In Balitbang Kesehatan, Depkes RI. https://doi.org/1 Desember 2013

Dinas Kesehatan Prov Bali. (2013). Laporan STP Dinas Kesehatan Provinsi Bali Tahun 2013.

Dinas Kesehatan Provinsi Bali. (2014). Data 10 Besar Penyakit di Puskesmas Sentinel Provinsi Bali.

Jelantik, I. G. M. G., \& Haryati, E. (2014). Hubungan Faktor Risiko Umur, Jenis Kelamin, Kegemukan dan Hipertensi dengan Kejadian Diabetes Melitus Tipe II di Wilayah Kerja Puskesmas Mataram. Media Bina Ilmiah39, 8(1), 39-44. Retrieved from http://www.lpsdimataram.com/phocadownload/Februari-2014/7-hubungan faktor risiko umur jenis kelamin kegemukan-jelantik haryati.pdf

Kemenkes RI. (2013). Riset Kesehatan Dasar (Riskesdas) 2013. In Badan Penelitian dan Pengembangan Kesehatan Kemenkes RI. https://doi.org/1 Desember 2013 
Soelistijo, S. ., Novida, H., Rudijanto, A., Soewondo, P., Suastika, K., Manaf, A., ... Zufry, H. (2015). Konsensus Pengelolaan dan Pencegahan Diabetes Melitus Tipe 2 di Indonesia. Pengurus Besar Perkumpulan Endokrinologi Indonesia (PB PERKENI).

Trisnawati, S. ., \& Setyorogo, S. (2013). Faktor Resiko Kejadian Diabetes Melitus Tipe II Di Puskesmas Kecamatan Cengkareng Jakarta Barat Tahun 2012. Jurnal Ilmiah Kesehatan, 5(1), 6-11. 